\title{
Chapter 4 \\ Against the Epistemicide. Itinerant \\ Curriculum Theory and the Reiteration of an Epistemology of Liberation
}

\author{
João M. Paraskeva
}

\begin{abstract}
The world of science has lost one of the most eminent figures and the race from which he sprang an outstanding member in the passing of Dr. George Washington Carver
\end{abstract}

Haber (1970, p. 104)

\begin{abstract}
Echoing Ettore Scola metaphor "Bruti, Sporchi \& Cativi", this chapter challenges how hegemonic and specific (or so called) counter hegemonic curriculum platforms - so connected with Western Eurocentric Modernity - have been able to colonize the field without any prudency to "fabricate" and impose a classed, raced and gendered philosophy of praxis, as unique, that drives the field to an ideological surrealism and collective suicide. Such collective suicide framed by a theoretical timesharing unleashed by both dominant and specific counter dominant platforms that tenaciously controlled the circuits of cultural production grooms the field as a ghetto, flooded with rudeness, and miserable ambitions, a theoretical caliphate that wipes out any episteme beyond the Western Eurocentric Modern terrain, insolently droving to sewage of society the needs and desires of students, teachers and the community.

Drawing from key decolonial thinkers, this chapter examines the way Western eugenic curriculum of modernity created an abyssal thinking in which 'this side' of the line is legitimate and 'the other side' has been produced as 'non-existent' (Sousa Santos B, Another knowledge is possible. Verso, London, 2007). The paper suggests the need to move a post-abyssal curriculum that challenges dominant and counter dominant traditions within 'this side' of the line, and respects 'the other' side of the line. The paper challenges curriculum studies to assume a non-abyssal position one that respects epistemological diversity. This requires an Itinerant Curriculum Theory
\end{abstract}

J.M. Paraskeva $(\bowtie)$

University of Massachusetts Dartmouth, North Dartmouth, MA 02747, USA

e-mail: jparaskeva@umassd.edu 
(Paraskeva JM, Conflicts in curriculum theory: Challenging hegemonic epistemologies. Palgrave Macmillan, London, 2011), which is a commitment and a ruthless epistemological critique of every existing epistemology.

Contrary to the nineteenth century in which, according to Marx and Engels (2012 [1848]) "a spectre [was] haunting [the Western civilization] - the spectre of communism [and that] all the powers of old Europe have entered into a holy alliance to exorcise this spectre - Pope and Tsar, Metternich and Guizot, French Radicals and German police-spies," at the end of the twentieth century beginning of the twenty first century, Western civilization is facing not just one a complex multiplicity of spectres. One of those is without a doubt the 'return of the repressed.' Although Eagleton (2011) and others are so right when they challenge the reductionist (and cheap) critic on Marx's framework, the truth of the matter is that 'the return of the repressed' cannot be explain historically as just a 'history of class struggles' since it is not just a political phenomenon. The field of curriculum studies here in the US and elsewhere cannot ignore these well-established conundrums.

Approaches, such as those of Mahbubani (2004), Sayyid (2015) or Haber (1970), testify to the importance of rethinking the way(s) internationalization debates have colonized the field - an issue that has caught the attention of many scholars in crucial settings, such as the American Association for the Advancement of Curriculum Studies. Sayyid's (2015) Fundamental Fear: Eurocentrism and the Emergence of Islam examines how modernity metamorphoses - anti, post, high, late, counter sweats full blast European nihilism in addressing the complex problems that were created by modernity. He (2015) claims:

Of the many spectres that have haunted western civilization from tine to time, perhaps none
is so perplexing or so irredeemably strange as the contemporary resurgence of Islam. The
spectral nature of this phenomenon arises not only from the way its emergence conveniently
coincides with the approach of the witching hour of the second Christian millennium, but
also from the way in which the Muslim presence for the West has tended to be grounded in
a 'hauntology' which finds it all too easy to conflate Muslims and ghosts. (p. 1)

While we are clearly facing a massive political issue, it is needless to add that such re-emergence "doesn't take only a political form" (Sayyid 2015, p. 4). The rise of such systematically repressed and in too many occasions - as history documents - butchered Islamic and other non-western civilizations goes hand in hand with the eugenic politics and praxis perpetrated by Western ideological apparatuses - such as 'the curriculum' - so well documented by Haber's (1970) Black Pioneers of Science and Invention.

Haber (1970) documents "significant contributions made by black scientists and inventors who were pioneers in various fields of science and the roles they played in the development of scientific progress in the United States" (p. vii). From inventors such as the genius Matzeliger (1852-1889) to whom "the modern shoe industry in [the US] and in the world is based upon his revolutionizing invention" (Haber 1970, p. 36) that was "patented on March 20, 1883" (Haber 1970, p. 46), to the "George 
Washington Carver Agricultural Chemist" (Haber 1970, p. 104), to "Garrett Morgan's Breathing helmet, patented on October 13, 1914" (Haber 1970, p. 93), 'another history' comes to the surface thus putting into question the knowledge that has been labeled as official bringing laudably to the fore the need to dismantled such curriculum epistemicide (Paraskeva 2014, 2016a).

Mahbubani's (2004) Can Asians Think? is a graphic example of the real color of what Mignolo (2013) and others frame as coloniality. He (2004) argues that "judging from the record of Asian societies over the past few centuries," Asians cannot think (p. 11); that is, societies "that take centuries to wake up cannot be said to think very well. It would be foolish for any Asian to deny [such] painful historical fact" (Mahbubani 2004, p. 11). Unfortunately, Mahbubani (2004) is not alone in such ideological statement. First, Mahbubani (2004) detached the history of colonialism and neocolonialism from a social constructed so-called darkness that drove nonWestern society to tough times in 'waking up' to use his own expression. In so doing, he also produces a specific eugenic historicity of history, one that denies irrefutable evidence of how inaccurate his claim is. Second, in so doing, Mahbubani (2004) not only strips such darkness from coloniality and its consequences. Such impossibility of wake up, according to him (2004), is due to the very Asian DNA that is devoid of any capacity to produce thinking and not a consequence of sanguinary centuries of imperial oppression. Such eugenic claim nulls any possibility of the oppressed to repel the oppressor and oppressed forms and to put themselves in a decolonial imaginary path (Perez 1999). Third, ignoring that right during the heyday of Enlightenment, "a number of prominent European political thinkers attacked imperialism not only defending non-European peoples against the injustices of European imperial rule, but also challenging the idea that Europeans had any right to subjugate, colonize, and 'civilize' the rest of the world" (Muthu 2003, p. 1).

As I have examined in other contexts (Paraskeva 2011, 2014, 2016a, b) Mahbubani (2004) and analyses such as his undermine that "to write about history is to write about of the lapses of history itself, of spaces blanked out by ruthless whiteness" (Young 2001, p. 1). Put it this way, "history is never is never for itself, it is always for someone" (Jenkins 1991, p. 21). Understanding Western Eurocentric history and its historicity as flooded by silences is perceiving not just the very color of coloniality, but also how such color was constructed right at the outset of colonialism. In 1670, Mbembe (2014) argues, "the big issue was how to create the conditions for a huge armada of labor to produce commodities from a far. The black ('o negro'; the other) addressed such challenge" (pp. 42-43). In fact, the black ('o negro'; the other) is the supreme invention of coloniality. Whereas on one hand, addressed the pressure for free labor, on the other raped Western democracies with an endemic issue; that is, "the fact that no black body arrived freely at the shores of the new world is a irresolvable problem for U.S. democracy" (Mbembe 2014, p. 147) - and one could add Western democracies.

When I was writing a new preface for the paperback edition of Conflicts in Curriculum Theory: Challenging Hegemonic Epistemologies (Paraskeva 2014), I remembered that a few years ago during a trip home, I came across an outstanding volume of Ezekiel Mphahlele's book in a shop in Hillbrow, Johannesburg. Mphahlele 
shares daily life stories of ordinary South Africans during the apartheid regime and discusses how such stories were crucial to understanding the complex struggle against oppression, poverty, and harsh inequality. There is a passage in the volume that I would like to highlight: "I want to write; I must write; I should write; I am going to write. This is what I said to myself one moonless night under an inky black sky ... [but] Write what? ... Why should I write?” (Mphahlele and Thuynsma 2011, p.7). With such words, South African intellectuals Ezekiel Mphahlele (known as Es'kia Mphahlele) and Peter N. Thuynsma (2011) begin “The Unfinished Story” in Corner B. Mphahlele and Thuynsma's questioning invokes for me so many other voices of intellectuals and countless horizons. Suddenly, I imagine a "trilogue" among Mphahlele, Steve Biko, and bell hooks. Biko (1978) would probably answer as follows: "You must write what you like." Quite rarely would hooks (1998) stress, "I write about work that does not move me deeply" (p. 137). However, Mphahlele would bring complexity to the arguments; one needs to say something to the world, and one needs to have something to say to the world. More to the point, one needs to have something to say to the world to be able to say something to the world. Mphahlele and Thuynsma insisted:

So much has been written on the Bantu, but I have always felt something seriously wanting in such literature. I told myself there must surely be much more to be said than the mere recounting of incident: about the loves and hates of my people; their desires; their property and affluence; their achievements and failures; their diligence and idleness; their cold indifference and enthusiasm; their sense of the comic; their full-throated laughter and their sense of the tragic with its attendant emotional sobs and ostentatious signs of pity. What could I say to the world?" (p. 14)

In writing Conflicts in Curriculum Theory: Challenging Hegemonic Epistemologies (Paraskeva 2011, 2014), I consciously faced the same challenges. Frustrated, like so many of us, with ambiguities and gaps within the vast and complex critical and poststructural terrains - despite the countless and crucial gains-I respectfully sought to go beyond such approaches and cautiously propose the need for an itinerant curriculum theory (ICT) to address the complex issues that we are all facing under the pressure of a liquid momentum (Bauman 1998), which characterize the current terrestrial globalization (Sloterdjik 2013). Arlene Croce (1998) argued that the critic has three options: "(1) to see and review, (2) to see and not review, and (3) not to see" (p. 16). She actually added a fourth option: "To write about what one has not seen; [that] becomes possible on strange occasions" (p. 16). ICT values not just the need to see and review; in fact, Conflicts in Curriculum Theory: Challenging Hegemonic Epistemologies does more than that. It reviews the field historically and addresses certain gains, strengths, and challenges of a particular radical/critical progressive river. By so doing, I claim a future-itinerary-path and justify why we need a critical itinerant approach, while being profoundly cautious about issuing any kind of recipe.

The field immediately reacted to ICT. Such reactions came from different Western and non-Western angles and epistemological axles, through varied informal and formal academic ways. Some were quite positive. Others raised justifiable concerns in particular cases, and others not only completely misrepresented ICT, but 
demonstrated by their objections precisely how important it is to challenge the epistemicide. It goes without saying that this is not an adequate space to address such reactions. But, for example, those who claim that I use ICT as an attack on JudeaChristian Western white male hegemonic epistemology-intentionally or nonintentionally-profoundly misinterpret the argument. ICT goes well beyond such notions. Other reactions, again some of them either welcoming and praising the merits of ICT or flagging understandable concerns, deserved attention, and I will likely address these concerns in the near future.

Needless to say, for so many liberals, epistemological differences are terribly inconvenient. Humanized capitalism, tempered with flamboyant forms of multiculturalism, are so dear to them and, in some cases, they are not even prepared to go that far. The problem is that "that far" is not enough. As Dwayne Huebner's words (personal communication, 2005) remind me repeatedly, "many educators are not necessarily magnanimous individuals — neither open to diverse ways of thought, nor to significant criticism. Welcome to the club."

ICT does try to say something to the field. It presents new terrains and theoretical situations. ICT participates in the complicated conversation (see Pinar 2000; Trueit 2000) - that cannot bend under the yoke of Western academicism-challenging Western curriculum epistemicides and alerting us to the need to respect and incorporate non-Western epistemes. William Pinar $(2012,2013)$ acknowledged the influential synopticality of ICT in his recent Curriculum Studies in the United States:

There are other discourses influential now, sustainability perhaps primary among them. Arts-based research is hardly peripheral ... One sign is the synoptic text composed by João M. Paraskeva. Hybridity is the order of the day. Pertinent to the discussion in that even Paraskeva's determination to contain in one "critical river" multiple currents of understanding curriculum politically floods its banks; he endorses an "itinerant curriculum theory" that asserts a "deliberate disrespect of the canon" $(2011,184)$. In Paraskeva's proclamation, this "river" has gone "south" $(2011,186)$. That South is Latin America, where we can avoid "any kind of Eurocentrism" $(2011,186)$ while not "romanticizing indigenous knowledge" $(2011,187)$. Addressing issues [such as hegemony, ideology, power, social emancipation, class, race, and gender] implies a new thinking, a new theory ... an itinerant curriculum theory. (Pinar 2013, p. 64)

Although Pinar's reading of ICT is crucial, I would clarify (maybe complexify) that "the" South is not just Latin America. Sousa Santos (2009) is vital here:

The South is metaphorically conceived as a field of epistemic challenges, which try to address and repair the damages and negative impacts historically created by capitalism in its colonial relation with the world. Such conception of South overlaps the geographical South, the group of nations and regions in the world that were subjugated to European colonialism and that, with the exception of Australia and New Zealand, never achieved levels of economic development similar to the Global North (i.e. Europe and the United States of America). (pp. 12-13)

Thus, we "designate the epistemological diversity of the world by South epistemologies" (Sousa Santos 2009, p. 12). In this way, ICT addresses Sousa Santos's (2006, p. xi) claim regarding the need for a new critical theory, a new emancipatory praxis that needs to be decolonized as well: 
Contrary to their predecessors, [such] theory and practices must start from the premise that the epistemological diversity of the world is immense, as its cultural diversity and that the recognition of such diversity must be at the core of global resistance against capitalism and of alternative forms of sociability. (p. xi)

ICT attempts to create an itinerant path to address a problem. In so doing, it faces undesirable yet unavoidable and needed black holes (Deleuze and Guattari 1987). ICT sees the confrontation with such holes as a reassembled set of processes toward a creative and desirable plan of consistency that is only possible by respecting a perpetual itinerancy. Such theory(ist) understands the structure and flows of a given social formation. Its itinerancy allows the theory(ist) to grasp the imposition, certification, and legitimization of particular un/re/coding metamorphoses, as well as the eclipse of so many others. ICT reads and challenges such codes that frame each social formation and fuel the wrangle of the oppressor-oppressed. This is crucial since it allows one to master the complex processes of axiomatization of specific codes within the capitalist society from slavery in the 1400 s to the current slavery constructions as de/re/coded flows of an economy and culture pumped by an epidemic of overproduction (Marx and Engels 2012).

ICT is an unblemished claim against dominant multiculturalist forms that are "Eurocentric, a prime expression of the cultural logic of national or global capitalism, descriptive, apolitical, suppressing power relations, exploitation, inequality and exclusion" (Sousa Santos 2007, pp. xxiii-xxiv) — that have been legitimizing a monoculture of scientific knowledge that needs to be defeated and replaced by an ecology of knowledges (Sousa Santos 2003a, b). ICT challenges the coloniality of power, being, knowledge, and labor (cf. Grosfoguel 2007; Mignolo 2000; Quijano 2000); it is sentient in that the "politics of cultural diversity and mutual intelligibility calls for a complex procedure of reciprocal and horizontal translation rather than a general theory" (Sousa Santos 2007, p. xxvi).

Formalizing ICT in my mind, through my writing, through dialogues with others and the wor(l)d, leads me to consider the intricacies of its conceptions and assertions. Yet, its conceptualization and creation comprise a natural complex interaction with the wor(l)d, as was perhaps the case for Michelangelo and Picasso with their art.

When one day Michelangelo was asked how a certain frame was painted, that is, where his idea came from, he answered, "I had no idea. The figure just stood there, looking at me. I just gave it life/birth.” Picasso had a similar dialogue with a Gestapo officer. In occupied Paris during World War II, a Gestapo officer who had barged into Picasso's apartment pointed at a photo of the mural, Guernica, asking, "Did you do that?" "No," Picasso replied, "you did." Writing is, Gilles Deleuze (1995) argued, "bringing something to life, to free life from where it's trapped, to trace lines of flight" (p. 141).

These words of Michelangelo and Picasso also highlight the theory of translation that works through art. Similarly, ICT is a theory of translation that attempts to prevent the "reconstruction of emancipatory discourse and practices from falling into the trap of reproducing, in a wider form, Eurocentric concepts and contents" 
(Sousa Santos 2007, p. xxvi). Translation is crucial to the processes of coding and decoding

between the diverse and specific intellectual and cognitive resources that are expressed through the various modes of producing knowledge about counter-hegemonic initiatives and experiences aimed at the redistribution and recognition and the construction of new configurations of knowledge anchored in local, situated forms of experience and struggle. (Sousa Santos 2007, p. xxvi)

In The Struggle for Meaning: Reflection on Philosophy, Culture and Democracy in Africa, Hountondji (2002, p. 26) confessed his search dilemmas under the supervision of Georges Canguilhem and later with Georges Balandier. Hountondji wanted to examine "all that history of ideas could teach us on the modes of existence of forms of knowledge and the conditions of the transition to science" (p. 26). Hountondji's ambition was to identify and delimit, within the existing corpus, something like an archeology of science and technology and apply it critically to Africa. Hountondji revealed the challenges in pursuing such object of study by engaging in a deep exegesis of Husserl's approach. Hountondji's approach is a vivid example of the inner challenges in examining Husserl without jeopardizing Africa as the focus of examination. Hountondji explained that his own strategy was his "struggle for meaning," which was to "work on the margins [and] to clear the field patiently, establish the legitimacy and the outlines of an intellectual project that was at once authentically African and authentically philosophical” (p. 78).

Examples such as Yacouba Sawadogo, an African farmer of Burkina Faso, who has been restoring the soil damaged by centuries of drought (and desertification) through traditional farming techniques, cannot be arrogantly minimized or eugenically produced as nonexistent or nonscience just because this work cannot be translated and framed within Western scientificity. Western intellectuals need to consciously acknowledge that the Western epistemological platform-both in its most sophisticated dominant and/or radical critical counterdominant perspectivesis insufficient and inadequate to explain and change its own effects (Seth 2011). A new system cannot emerge from the ashes of the old. It is pointless to think about the future solely with(in) the Cartesian modernity model. It is actually hopeless to frame the present within such a dated model.

Western counterdominant perspectives are crucial in the struggle for social and cognitive justice, yet they are not enough. As Sandra Corazza (2002) courageously argued, "we need to start taking seriously the task of a real theory of curriculum thought" (p. 131), one that opens the Western canon of knowledge and is responsive to the need for a new epistemological configuration. Such a journey of belligerent struggles - against dominant and within the counterdominant Western epistemological platform-aims to replace the so-called monoculture of scientific knowledge for an ecology of knowledges. Such ecology of knowledges is

an invitation to the promotion of non-relativistic dialogues among knowledges, grating equality of opportunities to the different kinds of knowledge engaged in ever broader epistemological disputes aimed both at maximizing their perspective contributions to build a more democratic and just society and at decolonizing knowledge and power. (Sousa Santos 2007, p. xx) 
As any other theoretical exercise aimed at understanding the educational world in order to transform it (see Pinar 2004), ICT certainly exhibits a latitude and longitude borderless space to deepen certain claims. For example, among many issues, ICT highlights the linguistic imperialism framed by the English language and culture as one part of the genocide. Conscious of this linguistic imperialism as a crucial part of the genocide, ICT allows one to respectfully understand, for example, how "camfrenglish"- "a language used in Cameron cities, invented [and] created daily by the Cameron's urban youth" (Ela 2013, p. 24)—a language that deliberately violates the linguistic rules of French and English, desacralizes such imperial languages Camfrenglish, in cities such as Yaonde, is the people's language.

Darder (2012), in her superb exegesis of the political economy of cultural theory and politics, brings language to the core of the battle against eugenics. As Darder (2012) claimed, "the complexity of language and how the students produce knowledge and how language shapes their world represent a major pedagogical concern for all educational settings" (p. 105). Language, Darder (2012) argued, is more than a tool that epitomizes a specific learning theory or the cult of a flamboyant method. The language question intersects other social nonepiphenomenons such as the question of authority, reframing equality and social and cognitive justice. Any critical theory that aims at cultural democracy cannot ignore the power of (noncelebratory forms of) biculturalism as a poesis that determines culture and power relations in the classrooms (Darder 2012).

ICT is a claim for a nonstop production of an epistemology of liberation, in the very best way promulgated by Sousa Santos, that rejects the perversity of colonial praxis of dominance based on "the ontic realization of Being" (Dussel 1995, pp. 44-45; see also Dussel 2013) and works based on and through a philosophy that liberates the very own liberatory philosophical posture-real philosophy of liberation that tries to

formulate a metaphysics - not an ontology demanded by revolutionary praxis and technodesign poesis against the background of peripheral social formations. To do this it is necessary to deprive Being of its alleged external and divine foundation; to negate fetishist religion in order to expose ontology as the ideology of ideologies; to unmask functionalisms - whether structuralist, logico-scientific, or mathematical (claiming that reason cannot criticize the whole dialectically, they affirm it more[;] they analytically criticize or operacionalize its parts); and to delineate the sense of liberation praxis. Only the praxis of oppressed peoples of the periphery, of woman violated by masculine ideology, of the subjugated child, can fully reveal it to us. (Dussel 1995, p. 15)

ICT consciously aligns with the need for an epistemology of liberation that requires the liberation of the epistemology itself. ICT also warns of the need to challenge any form of indigenitude or the romanticization of the indigenous cultures and knowledges, and it is not framed in any dichotic skeleton of West-rest. In fact, it challenges such functionalist forms. Its itinerant dynamic pushes the theorist to a pluri(nonnecessary) directional path.

More importantly, ICT confronts and throws the subject to a permanent unstable question of "what is there to think?" ICT pushes one to think in the light of the future as well as to question how "we" can actually claim to really know the things 
that "we" claim to know, if "we" are not ready specifically to think the unthinkable, to go beyond the unthinkable and master its infinitude. ICT is to be (or not to be) radically unthinkable. ICT is a metamorphosis between what is thought and nonthought and unthought, but it is fundamentally about the temerity of the colonization of the non/un/thought within the thought. ICT attempts to understand how big is infinite, the infinite of thought and action. If one challenges infinity, it is chaos because one is in chaos; that means that the question or questions (whatever they are) are inaccurately deterritorialized and fundamentally sedentary. The focus is to grasp that ICT implies an understanding of chaos as domestic, as public, as a punctum within the pure luxury of immanence. In such multitude of turfs, ICT needs to be understood as poesis. It plays in the plane of immanence. Being immanence, "a life," ICT is "a life.” Is it a life paced by a poesis or a revolution? Yes please, in a full Žižekian way. ICT is a poesis that itinerantly throws the subject against the infinite of representation to grasp the omnitude of the real(ity) and the rational(ity), thus mastering the transcendent. Being more poesis than just theory (and not because it is less theory), its itinerant position epitomizes a transcendent nomadography, which is not transcendental.

ICT challenges book worship (Tse Tung 2007, p. 45). In fact, ICT also encourages us to pay attention to the multiplicity of forms to read the wor(l)d. The verbalization of pain and oppression is quite visible in Africa, for example, in art forms, such as dance and painting. Dance, Ela (2013) argued, in a country financially and economically moribund, is not just a way to face inequality and oppression. It is, he stated, "the very best way to face discouragement" (p. 26). ICT is an attempt to help us to think in another form as a human being. Corazza's (2002) insightful framework is crucial here as well. As she claimed, and I honestly think ICT addresses her claim, the challenge is to fight against what she coined assentado curriculum toward a vagamundo curriculum; that is, "to create [or co-create] a vagamundo curriculum one needs to question how can one think about the unaddressable, the unthinkable, the non-thinkable of the curriculum thought, the exteriorities, the self different, the self other, the other self" (p. 140). Corazza added the following:

Such curriculum thought is meaningless, a real vacuum, without the effective forces acting upon such thought, as well as without the effective indeterminations that forces such thought [or forms of thought] to think otherwise, differently, through the creation of new concepts required by the real experience and not just by the possible experience, thus allowing new life experiences. [In fact,] the strength of (an)other knowledge, as well as a new philosophy, will be measured by the concepts that it is capable of creating, or its capacity to renew meanings which impose a new framework on things and to assentados actions, shuffle their syntax, and organizing its thought in a clumsy logic. (p. 140)

Corazza's sharp take equips intellectuals with the necessary extraordinary tools to understand why some African scholars, such as Axelle Kabou (2013), Jean-Marc Ela (2013), and others, justifiably counterargue the Western and non-Western hegemonic apparatuses with the following question: "What if Africa refuses development?"

The definition of development must be seen through other lenses beyond its Western monocultural conceptualization of the needed development for the global 
South. Whose purpose does this development serve? What is the cost to those beneath its grinding wheel of so-called progress? In such context, ICT is really a matter of human rights as well, due to its commitment to social and cognitive justice. This is a commitment that challenges dominant multicultural forms, creating the conditions for and intercultural reconstruction of human rights, toward intercultural postimperial human rights that respect, among other issues, (a) the right to knowledge, (b) the right to bring historical capitalism to trial in a world tribunal, (c) the right to democratic self-determination, and (d) the right to grant rights to entities incapable of bearing duties, namely nature and future generations (Sousa Santos 2007).

ICT is a clarion call to challenge curriculum epistemicides by engaging fully in the complex struggle for social and cognitive justice. This is an intergenerational matter of justice, as well. ICT is seeing to rely on Saramago's metaphor. In one of his best novels, Seeing, Nobel Prize winner and Portuguese intellectual, Saramago (2007) described pictorially how, with the vote, the citizens of one unidentified country (most likely Portugal) blocked the normal rhythms of daily life. On a typical gray, wet, winter day in Portugal, the huge majority of the population decided to not vote until late afternoon. The narrative explains the gradual panic of politicians who didn't know what to do before such a democratic scandal. Suddenly, almost at the end of the day, the citizens showed up and voted. Shockingly, after counting the votes, officials announced that the majority of the votes were blank. Such political embarrassment was examined and a lot of reasons came to the table, including the unpleasant weather conditions. The government scheduled another election the following week on a very pleasant and sunny day. To national consternation, the results were worse: More than $80 \%$ of the votes were blank. The government reacted immediately against such outcome as if a crime had been committed. A state of emergency was put in place; such state paved the way for a state of siege, with intelligentsia spying on citizens, taking them for interrogation, and administering liedetector tests. The story goes on with surreal examples narrated by Saramago.

Saramago's (2007) Seeing is crystal clear for those of us fully committed to the struggle against epistemicides. Seeing goes well beyond the understanding of how to use democracy to save democracy. It is a call for a blank vote for those of us committed to social and cognitive justice, not just against the modern Western dominant and specific counterdominant forms that colonize the very way we [can] think but also against the complex matrix of circuits of cultural production so well unmasked by Ahmad (2008), as well as our own very existence in our academic settings. In claiming a "seeing" position, ICT allows us to move on toward a world that we wish to see, a world that was proposed in the Bamako Appeal:

(1) a world based on solidarity among human beings and peoples, (2) a world based on the full and complete affirmation of citizenship and equality between the sexes, (3) a universal civilization that offers the greatest possibility for the creative development of the diversity in all areas, (4) a world that constructs civilization through real democracy, (5) a world based on the recognition of the non-commodity status of nature, the planet's resources and agricultural lands, (6) a world based on the recognition of the non-commodity status of cultural products, scientific knowledge, education and health, (7) a world that promotes policies that closely combine unlimited democracy, social progress, and the affirmation of the autonomy of all the nations and peoples, (8) a world that affirms the solidarity of the 
people of the north and the south in the construction of internationalism on an anti-imperialist foundation. (Amin 2008, pp. 108-111)

More to the point, and, as I mentioned in Conflicts in Curriculum Theory: Challenging Hegemonic Epistemologies (Paraskeva 2011), ICT will not please everyone, as I was able to observe in certain academic settings (to be honest, more so in the United States). While there are appeals for a copresence conversation to rub Sousa Santos's (2009) and Pinar's (2004) approaches against each other, it is not a cross-cultural conversation. We actually need to challenge the cult of cross-cultural conversations. Al-Azmeh (2009) helped a great deal here. One needs to radically question the notion of cross cultural conversation,

Not because [one] wishes there to be an eternal incomprehensibility between peoples, or because I wish to promote xenophobia, and encourage ethnic cleansing and correlative acts of barbarism. It is rather because I believe that the notion of cross cultural conversations rests upon an unreflected assumption of the fixity and finality of the interlocutors in this conversation which even at the ends of serious philosophical authors tends to cause reason to denigrate to the tritest statements on common maximums of etiquette. It is the very same assumption of fixity and irreducibility underlying the etiquette of interculturalism and multiculturalism as a form of conservatism etiquette, that [one] sees so apparently paradoxical correlative of the sorts of assumptions about others - other ethnoi, other religious groups-that prepare the grounds, in the realms of conceptions and imagination for the entire range of possibilitiesextending from the rapturous fascination with the exotic at one extremity, to bellicose dehumanization of the Other and genocidal dehumanization of the Other. (Azmeh 2009, p. 77)

As I discussed elsewhere (Paraskeva 2016b), this project attempts to address many of the important questions that have been raised regarding "internationalization." It attempts to bring to the fore voices/discourses that have been systematically produced as nonexistent. This project is part of a long itinerant, deterritorialized, decolonial walk, a mirror of a complex dialogue among many of us, a dialogue that keeps targeting major conceptual swamps, such as the following: What does one mean by "internationalization"? Whose "internationalization"? Which language dominates this "internationalization"? Whose voices have been silenced? Whose knowledge has been systematically dismissed, ignored, and produced as nonexistent? I reiterate that an emphasis should be placed on what Sousa Santos (2014) called epistemicides and that I championed in the field as "curriculum epistimicides."

By championing the commitment to a nonabyssal thinking and defying the eugenic cult of cross culturalism, ICT put forward, along with Mignolo (2000, 2013) and Escobar (2013), and others, un paradigma otro that "does not fit into a linear history of paradigms or epistemes [that] runs counter to the greatest modernist narratives [and] reaches towards the possibility of non-European modes of thinking" (Escobar 2013, p. 34).

Such paradigm otro frames and fuels the debate of Western modernity within the so-called modernity/coloniality research program (Escobar 2013, p. 33) that challenges dominant perspectives in the study of modernity that could well be framed as "intramodern perspectives" (Escobar 2013, p. 34). Eurocentered Western modernity cannot be dissociated from the quarrel of global-local, and, "as a particular local 
history-[it] lays in the fact that it has produced particular global designs in such a way that it has 'subalternized' other local histories and their corresponding designs" (Escobar 2013, p. 38; Mignolo 2013).

The modernity/coloniality research project (hereafter MC) conceptualizes such colonial-coloniality momentum "grounded in a series of events [social constructions] that distinguished it from established theories of modernity" (Escobar 2013, p. 38). That is,

(1) an emphasis on locating the origins of modernity with the Conquest of America and the control of the Atlantic after 1492, rather than in the most commonly accepted landmarks such as the Enlightenment of the end of the eighteen century; (2) a persistent attention to colonialism and the making of the capitalism world system as constitutive of modernity; (3) the adoption of a world perspective in the explanation of modernity, in lieu of a view of modernity as an intra-European phenomenon; (4) the identification of the domination of others outside the European core as a necessary dimension of modernity with the concomitant subalternization of knowledge and cultures of these other groups; (5) a conception of Eurocentrism as the knowledge form of modernity/coloniality - a hegemonic representation and mode of knowing that claims universality for itself. (Escobar 2013, p. 38)

Such MC frames its research agenda by emphasizing notions such as the following:

(a) modern colonial world system - as an assemble of processes and social formations that encompass modern colonialism and colonial modernities; (b) coloniality of power-a global hegemonic model of power in place since the conquest that articulates race and labor and peoples according to the needs of capital and to the benefit of white peoples; (c) colonial difference and global coloniality - which refer to the knowledge and cultural dimensions of the subalternization processes effected by the coloniality of power; the colonial difference brings to the fore persistent cultural differences within global power structures; (d) coloniality of being - as an ontological dimension of coloniality on both sides of the encounter; (e) Eurocentrism - as the knowledge model that represents the local European historical experience and which became globally hegemonic since the seventeenth century. (Escobar 2013, p. 39)

ICT needs to be seen in such a framework as well. It is sentient of MC, yet it is not exhausted by it. Its itinerant perpetual dynamic creates that incapacity of surrender to a concrete framework. However, ICT attempts to complexify MC. For instance, it does not necessarily "run counter the greatest modernist narratives" (Escobar 2013, p. 34). It definitely runs against dominant modernist great narratives and through some counterdominant modernist great narratives, such as Marxism, for example, and in so doing decolonizes it. However, even in the attempt to smash certain dominant Western modernist great narratives, ICT pays cautious attention to the wrangle of religion, that is, Christianity and spirituality and how such a yarn was/is crucial to the construction of the (non)existence of the "other" (see Ela 2013). In such a sense, ICT is a theory of liberation, a liberation from certain constraints of critical pedagogy, as well, without denying it. Critical pedagogy exhibits particular pedagogical forms

as part of an ongoing individual and collective struggle over knowledge, desire, values, social relations, and modes of political agency[; that is,] critical pedagogy is central in drawing the attention to questions regarding who has control over the conditions for the 
production of knowledge, values and classroom practices; [critical pedagogy] is a form of provocation and challenge [attempting] to take people beyond the world they are familiar with and makes clear how classroom knowledge [is] always implicated in power. (Giroux 2011, pp. 5-6)

ICT sees such a "collective struggle over knowledge" as a struggle that today needs to go well beyond the Western epistemological platform. We all stand respectfully in the shoulders of others, and Giroux's (2011) work helps a great deal. By insightfully framing critical theory and pedagogy as a language of critique and hope and possibility, a critical pedagogy "that addresses the democratic potential of engaging how experience, knowledge and power are shaped in the classroom in different and often unequal contexts" (Giroux 2011, p. 5), he built a foundational field that one can explore in the struggle against epistemicides. ICT is a clear call against the precariousness of any fixed theoretical position. Needless to say, this implies severe conflict, a conflict that was always a part of our daily lives. ICT is the people's theory, an epistemology of liberation quite sentient that there is no theoretical and/or political incompatibility between Marxist critical impulses and non-Western epistemes. For instance, if one pays close attention to Giroux's language of hope and possibility and the way that he frames critical theory and pedagogy, one does not see any incompatibility for an itinerant curriculum theorist to rub against other critical Marxist impulses and non-Western epistemes. This clearly implies decolonizing processes within the very core of the critical and Marxist matrix. Isn't this what Marx actually alerted us to when he claimed the need for a ruthless critique of everything that exists?

\section{References}

Ahmad, A. (2008). In theory. London: Verso.

Al-Azmeh, A. (2009). Islams and modernities. New York: Verso.

Amin, S. (2008). The world we wish to see: Revolutionary objectives in the twenty-first century (pp. 107-112). New York: Monthly Review Press.

Bauman, Z. (1998). Globalization: The human consequences. London: Blackwell.

Biko, S. (1978). I write what I like. Johannesburg: Heinemann.

Corazza, S. M. (2002). Noologia do currículo: Vagamundo, o problemático, e assentado, o resolvido. Educação e Realidade, 27(2), 131-142.

Croce, A. (1998). Discussing the undiscussable. In M. Berger (Ed.), Crisis of criticism (pp. 15-29). New York: The New Press.

Darder, A. (2012). Culture and power in the classrooms: Educational foundations for the schooling of bicultural studies. Boulder: Paradigm.

Deleuze, G. (1995). Negotiations 1972-1990. New York: Columbia University Press.

Deleuze, G., \& Guattari, F. (1987). A thousand plateaus: Capitalism and schizophrenia. Minneapolis: University of Minnesota Press.

Dussel, E. (1995). Philosophy of liberation. Eugene: Wipf and Stock.

Dussel, E. (2013). Ethics of liberation: In the age of globalization and exclusion. Durham: Duke University Press.

Eagleton, T. (2011). Why Marx was right. New Haven: Yale University Press.

Ela, J. M. (2013). Restituir a Historia as Sociedades Africanas. Lisbon: Edicoes Pedago. 
Escobar, A. (2013). Words and knowledges otherwise. In W. Mignolo \& A. Escobar (Eds.), Globalization and the decolonial turn (pp. 33-64). New York: Routledge.

Giroux, H. (2011). Zombie politics in the age of casino capitalism. New York: Peter Lang.

Grosfoguel, R. (2007). The epistemic decolonial turn: Beyond political economy paradigms. Cultural Studies, 21(2-3), 211-223.

Haber, L. (1970). Black pioneers of science and invention. Orlando: Odyssey Classic Hardcourt.

Hooks, B. (1998). Making movie magic. In M. Berger (Ed.), The crisis of criticism (pp. 132-146). New York: The New Press.

Hountondji, P. (2002). The struggle for meaning: Reflection on philosophy, culture and democracy in Africa. Athens: Ohio State University.

Jenkins, K. (1991). Re-thinking history. London: Routledge.

Kabou, A. (2013). E se a Africa se Recusar ao Desensvolvimento? Lisbon: Edicoes Pedago.

Mahbubani, K. (2004). Can Asians think? Singapore: Marshal Cavendish International.

Marx, K., \& Engels, F. (2012). The communist manifesto. New York: Verso.

Mbembe, A. (2014). Critica da Razao Negra. Lisboa: Antigona.

Mignolo, W. (2000). Local histories/global designs: Coloniality, subaltern knowledges and border thinking. Princeton: Princeton University Press.

Mignolo, W. (2013). Introduction. Coloniality of power and decolonial thinking. In W. Mignolo \& A. Escobar (Eds.), Globalization and the decolonial turn (pp. 1-21). New York: Routledge.

Mphahlele, E., \& Thuynsma, P. N. (2011). In corner B (pp. 15-29). New York: Penguin Classics.

Muthu, S. (2003). Enlightenment against the empire. Princeton: Princeton Univrsity Press.

Paraskeva, J. M. (2011). Conflicts in curriculum theory: Challenging hegemonic epistemologies. London: Palgrave Macmillan.

Paraskeva, J. M. (2014). Conflicts in curriculum theory: Challenging hegemonic epistemologies. London: Palgrave Macmillan.

Paraskeva, J. M. (2016a). Curriculum epistemicides. Towards an itinerant curriculum theory. New York: Routledge.

Paraskeva, J. M. (2016b). Introduction. In J. M. Paraskeva (Ed.), The curriculum: Whose internationalization? (p. XX). Peter Lang: New York.

Perez, E. (1999). Decolonial imaginary. writing Chicanas into history. Bloomington: Indiana University Press.

Pinar, W. (2000). Introduction: Toward the internationalization of curriculum studies. In D. Trueit, W. Doll Jr., H. Wang, \& W. Pinar (Eds.), The internationalization of curriculum studies (pp. 1-13). New York: Peter Lang.

Pinar, W. (2004). What is curriculum theory? Mahwah: Lawrence Erlbaum.

Pinar, W. (2012). Curriculum studies in the United States. New York: Palgrave Macmillan.

Pinar, W. (2013). Curriculum studies in the United States: Present circumstances, intellectual histories. New York: Palgrave Macmillan.

Quijano, A. (2000). Colonialidad del poder y classificacion Social. Journal of World Systems Research, 6(2), 342-386.

Saramago, J. (2007). Seeing (Reprint ed.). Washington: Harvest Books.

Sayyid, S. (2015). Fundamental fear. Eurocentrism and the emergence of Islam. London: ZED Books.

Seth, S. (2011). Travelling theory: Western knowledge and its Indian object. International Studies in Sociology of Education, 21(4), 263-282.

Sloterdjik, P. (2013). In the world interior of capital: Towards a philosophical theory of globalization. Cambridge: Polity Press.

Sousa Santos, B. (2003a). Prefácio. In B. Sousa Santos (Ed.), Democarizar a Democracia-Os caminhos da Democracia Participativa (pp. 25-33). Porto: Edições Afrontamento.

Sousa Santos, B. (2003b). Para uma sociologia das ausências e uma sociologia das emergências. In B. Sousa Santos (Ed.), Conhecimento prudente para um vida decente: Um Discurso sobre as ciencias revisitado (pp. 735-775). Porto: Afrontamento. 
Sousa Santos, B. (2006). The rise of the global left: The world social forum and beyond. London: Verso.

Sousa Santos, B. (2007). Another knowledge is possible. London: Verso.

Sousa Santos, B. (2009). Epistemologias do sul. Coimbra: Almedina.

Sousa Santos, B. (2014). Epistemologies from the South. Boulder: Paradigm.

Trueit, D. (2000). Democracy and conversation. In D. Trueit, W. Doll Jr., H. Wang, \& W. Pinar (Eds.), The internationalization of curriculum studies (pp. ix-xvii). New York: Peter Lang.

Tse Tung, M. (2007). Oppose book worship. In S. Žižek (Ed.), Slavoj Žižek presents Mao on practice and contradi ction (pp. 43-51). London: Verso.

Young, R. (2001). White mythologies. London: Routledge.

Open Access This chapter is licensed under the terms of the Creative Commons Attribution 4.0 International License (http://creativecommons.org/licenses/by/4.0/), which permits use, sharing, adaptation, distribution and reproduction in any medium or format, as long as you give appropriate credit to the original author(s) and the source, provide a link to the Creative Commons license and indicate if changes were made.

The images or other third party material in this chapter are included in the chapter's Creative Commons license, unless indicated otherwise in a credit line to the material. If material is not included in the chapter's Creative Commons license and your intended use is not permitted by statutory regulation or exceeds the permitted use, you will need to obtain permission directly from the copyright holder. 